\title{
Deriving Field-Based Ecological Risks for Bird Species
}

\author{
Renske P. J. Hoondert, ${ }^{*}{ }^{\dagger}$ Jelle P. Hilbers, ${ }^{\dagger}$ A. Jan Hendriks, ${ }^{\dagger}$ and Mark A. J. Huijbregts ${ }^{\dagger}$ \\ ${ }^{\dagger}$ Institute for Water and Wetland Research, Department of Environmental Science, Radboud University, P.O. Box 9010, \\ Heyendaalseweg 135, 6525 AJ Nijmegen, The Netherlands
}

\author{
Supporting Information
}

ABSTRACT: Ecological risks (ERs) of pollutants are typically assessed using species sensitivity distributions (SSDs), based on effect concentrations obtained from bioassays with unknown representativeness for field conditions. Alternatively, monitoring data relating breeding success in bird populations to egg concentrations may be used. In this study, we developed a procedure to derive SSDs for birds based on field data of egg concentrations and reproductive success. As an example, we derived field-based SSDs for $p, p^{\prime}$-DDE and polychlorinated biphenyls (PCBs) exposure to birds. These SSDs were used to

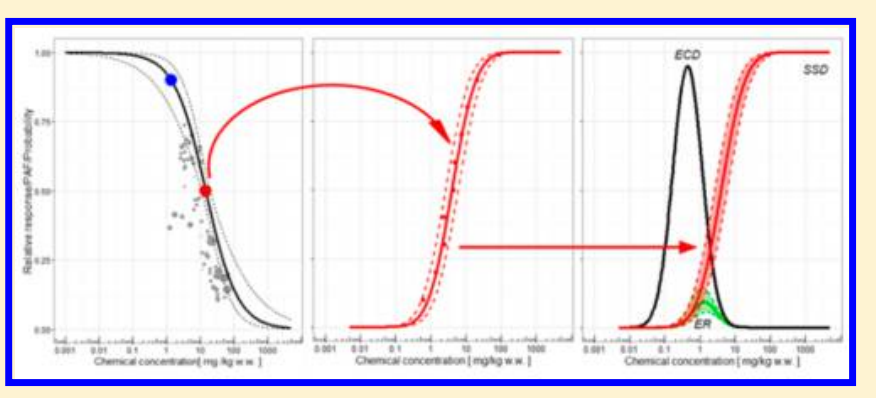
calculate ERs for these two chemicals in the American Great Lakes and the Arctic. First, we obtained field data of $p, p^{\prime}-\mathrm{DDE}$ and PCBs egg concentrations and reproductive success from the literature. Second, these field data were used to fit exposure-response curves along the upper boundary (right margin) of the response's distribution (95th quantile), also called quantile regression analysis. The upper boundary is used to account for heterogeneity in reproductive success induced by other external factors. Third, the species-specific $\mathrm{EC}_{10 / 50} \mathrm{~s}$ obtained from the field-based exposure-response curves were used to derive SSDs per chemical. Finally, the SSDs were combined with specific exposure data for both compounds in the two areas to calculate the ER. We found that the ERs of combined exposure to these two chemicals were a factor of 5-35 higher in the Great Lakes compared to Arctic regions. Uncertainty in the species-specific exposure-response curves and related SSDs was mainly caused by the limited number of field exposure-response data for bird species. With sufficient monitoring data, our method can be used to quantify field-based ecological risks for other chemicals, species groups, and regions of interest.

\section{INTRODUCTION}

In current ecological risk assessment, chemical risks are often evaluated using species sensitivity distributions (SSDs). ${ }^{1-3}$ The main assumption of an SSD is that the differences in sensitivity of species toward a chemical can be described by a (cumulative or probabilistic) distribution function. ${ }^{4,5}$ SSDs can be used to calculate the ecological risk (ER) posed by individual compounds and compound groups to species in an area. ${ }^{6}$ ERs are defined as the probability of measured environmental concentrations exceeding (no) effect concentrations of species. ${ }^{6,7}$ Effect concentrations, such as half maximal effective concentrations $\left(\mathrm{EC}_{50} \mathrm{~s}\right)$ or no-observed-effect concentrations (NOECs), are typically obtained from lab experiments. In these experiments, individual performance (e.g., fecundity or mortality) is measured in a controlled setting. The application of these data in the derivation of SSDs has been subject to much discussion over the years as lab data fail to acknowledge potential differences with site-specific conditions. ${ }^{9}$ Furthermore, although the use of a wide range of species when quantifying toxicant-effect relationships is more representative of actual impacts in bird populations, ${ }^{10}$ test species used in these experiments are limited to those that are easy to breed and do not necessarily reflect natural compositions of taxonomical groups. ${ }^{9,11,12}$ Ecotoxicological data is lacking for many bird species at higher trophic levels (e.g., piscivores, raptors, and insectivores), as laboratory experimentation is limited due to practical, financial, and ethical constraints ${ }^{13}$ or focus on acute lethal toxicity only.

Field monitoring data of breeding success in bird populations and related chemical concentrations in eggs may be used as an alternative to laboratory experiments in the derivation of effect concentrations as input for the SSDs for birds. However, it is important to isolate the impact of individual chemicals as breeding success is influenced by a variety of additional environmental or biological factors, such as climate and population density. ${ }^{14}$ Traditional statistical regression approaches focus on changes in the mean of the response variable's distribution only, including the effects of other extraneous variables and introducing potential bias. Instead of using traditional regression analysis, quantile regression may be used to account for hidden bias resulting from extraneous environmental variables. $6,15,16$

By fitting a sigmoidal exposure-response curve at the upper boundary of the data's distribution, the constraints of elevated toxicant concentrations in eggs imposed on bird reproductive success are expected to become visible, as it corrects for unmeasured ecological and environmental factors (hidden bias)

Received: November 17, 2017

Revised: February 12, 2018

Accepted: February 27, 2018

Published: February 27, 2018 
potentially limiting the observed response. ${ }^{16}$ In this way, constraints imposed solely by chemical exposure are expected to be revealed.

The aim of the present study was to develop and apply a procedure to derive ecological risks of bird species, based on field data of reproductive success and chemical concentrations in eggs of birds. As an example, we applied the procedure with field data on $p, p^{\prime}$-DDE (dichlorodiphenyldichloroethylene, a DDT metabolite) and the sum of multiple PCB congeners in the North American Great Lakes and the Arctic. The effects of DDT metabolites and polychlorinated biphenyls (PCBs) on bird species have received much attention since the early 1960s. ${ }^{17,18}$ These compounds are known to be persistent and are strongly linked to eggshell thinning, altered sexual behavior, and hormonal disruption, ${ }^{19,20}$ which in turn decrease growth rates in bird populations.

\section{MATERIALS AND METHODS}

Quantile Regression. Fitting Procedure. Relative reproductive success (fraction) was related to a toxicant gradient using the quantile regression approach as described by Koenker, ${ }^{21}$ where the regression line was fitted to the 95th quantile $(\tau=0.95)$ of the response variable's distribution, to account for heterogeneity caused by other limiting ecological and environmental factors. The quantile regression model was based on the Hill equation, ${ }^{22-24}$ yielding a sigmoidal curve

$$
R_{i, j}=\frac{1}{1+\left[\frac{\mathrm{EC}_{50 i, j}}{C_{j}}\right]^{\beta_{i, j}}}
$$

where $R_{i, j}$ is the modeled response (relative reproductive success) of species $i$ for chemical $j, \mathrm{EC}_{50 i, j}$ is the $50 \%$ effective response level or inflection point of the curve of species $i$ for chemical $j, C_{j}$ is the measured contaminant concentration of chemical $j$ (in $\mathrm{mg} / \mathrm{kg}$ egg wet weight), and $\beta_{i, j}$ is the slope coefficient associated with species $i$ for chemical $j$, determining the slope of the curve. ${ }^{22,24} \mathrm{We}$ fitted a logit transformed regression line on the data set using the quantreg package of Koenker (2013), ${ }^{21}$ adapted from Bottai et al. $2010^{25}$ as

$$
\operatorname{logit}(R)=\beta_{0}+\beta_{i, j} \cdot \operatorname{LN}(C)
$$

implying that the untransformed relative reproductive success can be calculated through

$$
R=\frac{\exp \left(\beta_{0}+\beta_{i, j} \cdot \operatorname{LN}(C)\right) \cdot\left(R_{\max }+\varepsilon\right)+\left(R_{\min }-\varepsilon\right)}{\exp \left(\beta_{0}+\beta_{i, j} \cdot \operatorname{LN}(C)\right)+1}
$$

where $\operatorname{LN}(C)$ is the natural log-transformed chemical concentration in the egg, $\beta_{0}$ is defined as the intercept of the regression line, and $\beta_{i, j}$ is the slope coefficient equal to $\beta_{i, j}$ in eq 1. $\varepsilon$ reflects the error term, in this study set at 0.001 , a small quantity ensuring that the logistic transform is defined for all values of $R .^{25}$ The quantile regression algorithm minimizes the residuals of the regression analysis. ${ }^{21}$ The inflection point of the exposure-response curve (or $\mathrm{EC}_{50}$ in eq 1 , in $\mathrm{mg} / \mathrm{kg}$ w.w.) was derived as

$$
\mathrm{EC}_{50}=\exp \left(\frac{\beta_{0}}{\beta_{i, j}}\right)
$$

The $\mathrm{EC}_{10}$ values were derived by solving eq 1 for $C$, fixing $R_{i, j}$ at $0.9,{ }^{26}$ using the uniroot function in R statistics 3.3.1. The $95 \%$ confidence intervals associated with the quantile fit were obtained by using bootstrapped errors, as described by Koenker. $^{27}$

Model Consistency. Regression lines were fitted at three additional quantiles $(\tau=0.25,0.5,0.75)$ to evaluate model consistency. We expected a negative relationship between exposure and response for all quantiles, i.e. a negative $\beta_{i, j}$. Furthermore, we expected that the larger the quantile, the larger the $\mathrm{EC}_{50^{-}}$and $\mathrm{EC}_{10^{-}}$-values. If both expectations were not met, data were not considered sufficiently reliable to derive an exposure-response relationship. The following selection criteria for the exposure-response curves were applied:

1) Exposure-response curves yielding a positive $\beta_{i, j}$ for $\tau=$ $0.95, \tau=0.75$, or $\tau=0.50$ were not further considered in the analysis.

2) Effect concentrations that have higher $\mathrm{EC}_{10^{-}}$or $\mathrm{EC}_{50^{-}}$ values for $\tau=0.25$ or $\tau=0.50$ compared to $\tau=0.95$ were disregarded.

Species Sensitivity Distributions. SSDs were constructed, using $\mathrm{EC}_{50}$ and $\mathrm{EC}_{10}$ data obtained from the derived exposure-response curves. We assumed a log-normal spread in species sensitivities for SSDs with mean $(\mu)$ and standard deviation $(\sigma)$ to link the toxicant gradient ( $x$-axis) to the potentially affected fraction of species (PAF; $y$-axis)., ${ }^{428,29}$ To assess the statistical uncertainty in the SSDs, we randomly sampled 10,000 $\mathrm{EC}_{10} \mathrm{~s}$ and $\mathrm{EC}_{50} \mathrm{~s}$ for each species-chemical combination separately, using the uncertainty in the quantile regressions as a starting point. Subsequently, for each chemical 10,000 SSDs were fitted through these sampled effect concentrations over all species under the assumption of a lognormal distribution.

Ecological Risks. The ecological risk (ER; fraction) is defined as the probability of a species in a certain area exceeding its $\mathrm{EC}_{10}$ or $\mathrm{EC}_{50}$ and represents the overlap between the derived SSD and the exposure concentration distribution (ECD) of a certain chemical in a specific area (as exemplified in Figure 1). ERs are calculated through integral ${ }^{6,7}$

$$
\mathrm{ER}=\int_{-\infty}^{\infty} \mathrm{PDF}_{\mathrm{ECD}} \cdot \mathrm{CDF}_{\mathrm{SSD}} \mathrm{d} x
$$

where $\mathrm{PDF}_{\mathrm{ECD}}$ is defined as the probability density function of the natural log-transformed exposure concentration distribution of an individual chemical found in bird's eggs in a specific area. $\mathrm{CDF}_{\mathrm{SSD}}$ is the (cumulative) single substance SSD model based on field-based $\mathrm{EC}_{10} \mathrm{~s}$ and $\mathrm{EC}_{50} \mathrm{~s}$.

ERs based on SSDs derived for respectively $\mathrm{EC}_{10} \mathrm{~s}$ and $\mathrm{EC}_{50} \mathrm{~s}$ for single toxicant exposure were calculated based on Korsman et al. $2016^{7}$ in $\mathrm{R}$ statistics 3.3.1 using

$$
\mathrm{ER}=\operatorname{pnorm}\left(\frac{\mu_{\mathrm{ECD}}-\mu_{\mathrm{SSD}}}{\sqrt{{\sigma_{\mathrm{ECD}}}^{2}+\sigma_{\mathrm{SSD}}^{2}}}\right)
$$

in which the function pnorm returns a probability distribution function and where $\mu_{\mathrm{SSD}}$ is the natural log-transformed mean of the SSD and $\sigma_{\mathrm{SSD}}$ reflects the natural log-transformed standard deviation of the SSD. The $\mu_{\mathrm{ECD}}$ and $\sigma_{\mathrm{ECD}}$ are the mean and standard deviation associated with the natural log-transformed contaminant concentrations found in bird's eggs in a certain area. $^{6}$ 


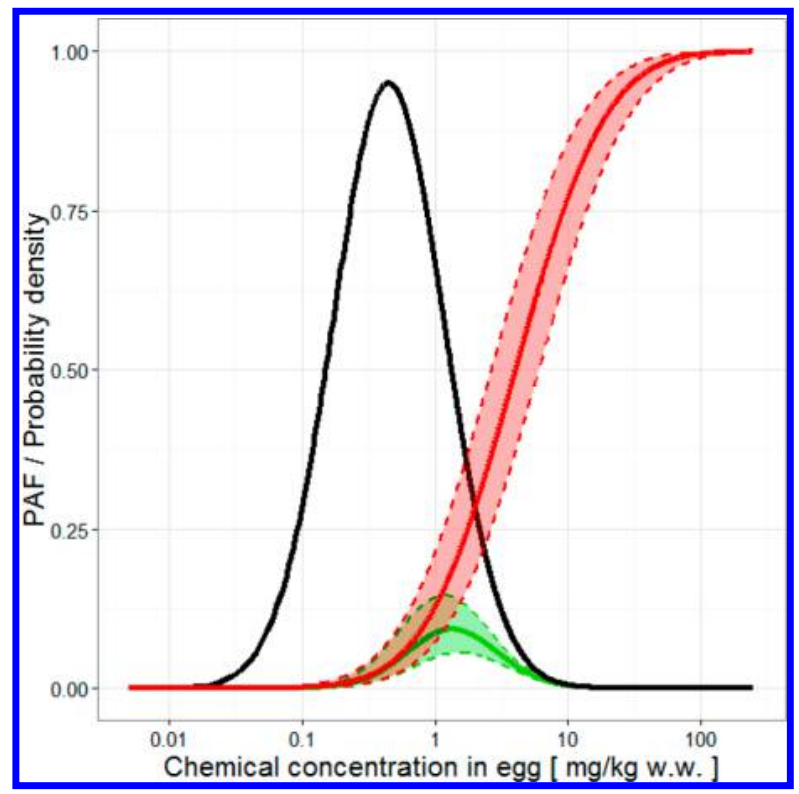

Figure 1. Graphical example of $\mathrm{CDF}_{\mathrm{SSD}}$ in red, corresponding $95 \%$ confidence intervals (dashed lines), $\mathrm{PDF}_{\mathrm{ECD}}$ in black, and ER (area under the curve), with corresponding $95 \%$ confidence intervals, in green.

Combined ecological risk $\left(\mathrm{ER}_{\mathrm{c}}\right)$, defined as the risk posed by multiple pollutants in an area, was calculated using eq 7 according to the response addition principle ${ }^{6,7}$

$$
\mathrm{ER}_{\mathrm{c}}=1-\prod_{i=1}^{n_{i}}\left(1-\mathrm{ER}_{\mathrm{i}}\right)
$$

where $n_{i}$ is the number of substances used in calculation of the $E R_{\mathcal{c}}$ and $E_{\mathrm{i}}$ is the ecological risk calculated for each compound individually. Statistical uncertainty in the ERs was quantified by random sampling from the SSD realizations, as mentioned above.

Data Acquisition and Treatment. Exposure-Response Data. A data set was compiled containing $p, p^{\prime}$-DDE and $\Sigma$ PCB concentrations in eggs (in $\mathrm{mg} / \mathrm{kg}$ wet weight) and the corresponding reproductive success of the bird (-population). The relative reproductive success of an individual bird (or population) was defined as the fraction of fledglings per occupied or active nest (productivity), over the species theoretical maximum productivity (the maximum productivity given in the full data set for that species, see Table S1 and eq S1 in the Supporting Information). Data were obtained from a literature search of the Web of Knowledge using search strings related to reproductive success and productivity, combined with species' names (scientific and common names) or terms such as birds and avian species on one side, and terms related to organic pollutants (specific compound names or compound groups) on the other. Additionally, data from scientific reports (gray literature) were obtained using Google Scholar, using the same search strings. This search revealed 57 potentially useful articles and reports, ${ }^{30-86}$ including monitoring data for four raptorial bird species or species groups (bald eagle (Haliaeetus leucocephalus), white-tailed eagle (Haliaeetus albicilla), Eurasian sparrowhawk (Accipiter nisus), and falcon species (including Falco peregrinus and Falco sparverius)), eight piscivorous bird species or species groups (osprey (Pandion haliaetus), herring gull (Larus argentatus), common tern (Sterna hirundo), cormorant species (including Phalacrocorax auritus, Phalocrocorax carbo, and Phalacrocorax pelagicus), brown pelican (Pelecanus occidentalis), snowy egret (Egretta thula), blackcrowned night heron (Nycticorax nycticorax), and black skimmer (Rynchops niger)), and three insectivorous birds (tree swallow (Tachycineta bicolor), house wren (Troglodytes aedon), and American robin (Turdus migratorius)). Contaminant concentration of egg given in terms of lipid or dry weight were converted to wet weight $(\mathrm{mg} / \mathrm{kg})$ using data on lipid or

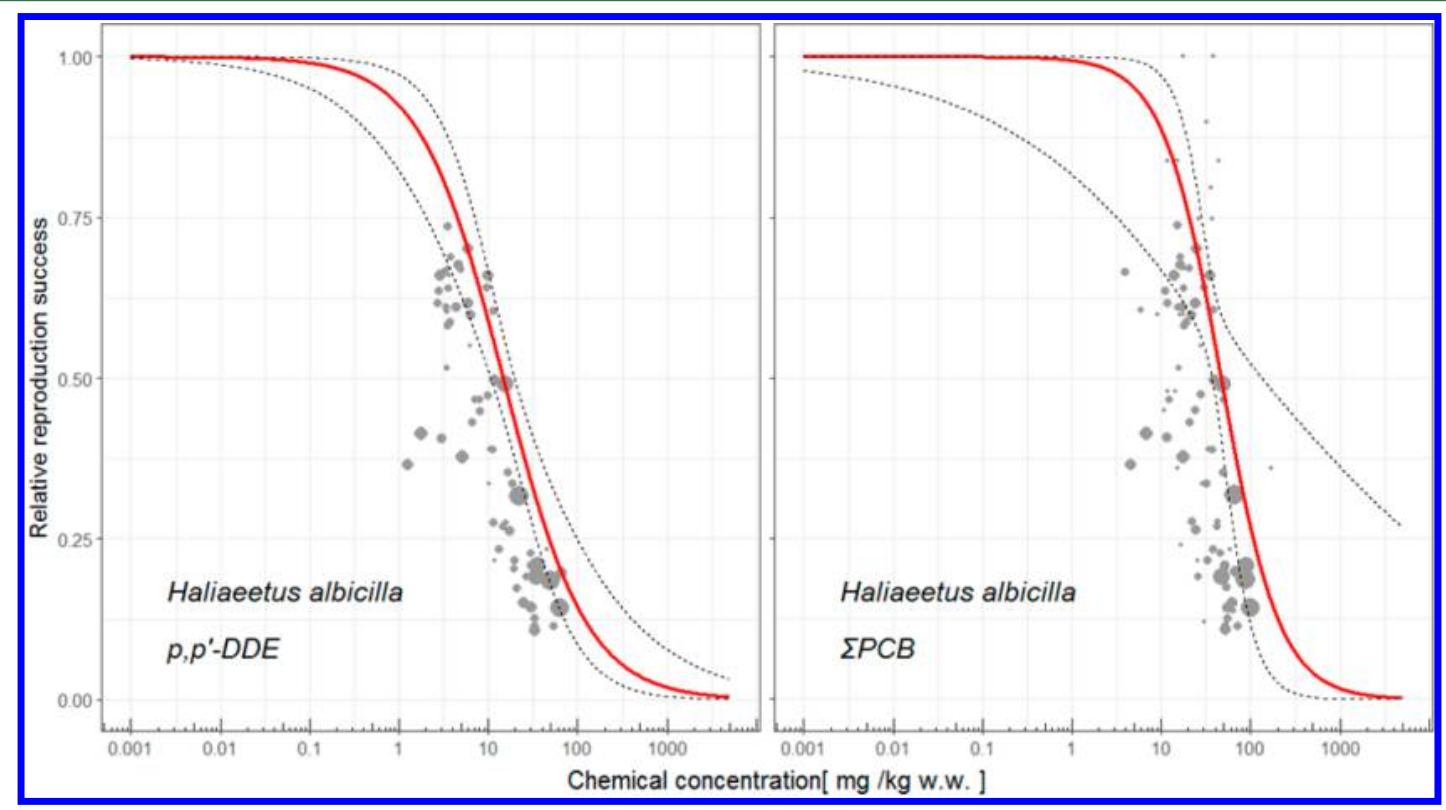

Figure 2. Quantile exposure-response curves plotting reduction in reproductive success at increasing chemical concentrations in eggs for the whitetailed eagle (Haliaeetus albicilla). Quantile $\tau$ was set at 0.95 . The scatter points correspond with single data records, and their size corresponds with the assigned weight. The $95 \%$ C.I. is indicated through dashed lines. Exposure-response curves for the other birds species included can be found in the Supporting Information (Figures S1 and S2). 


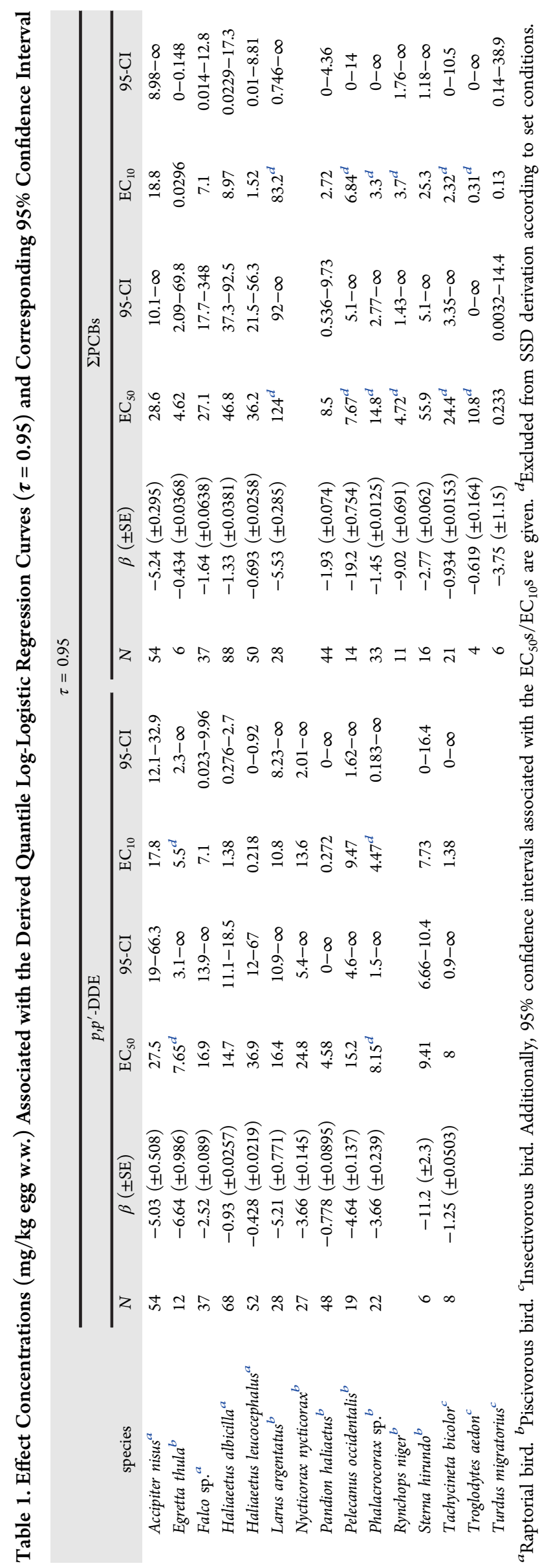




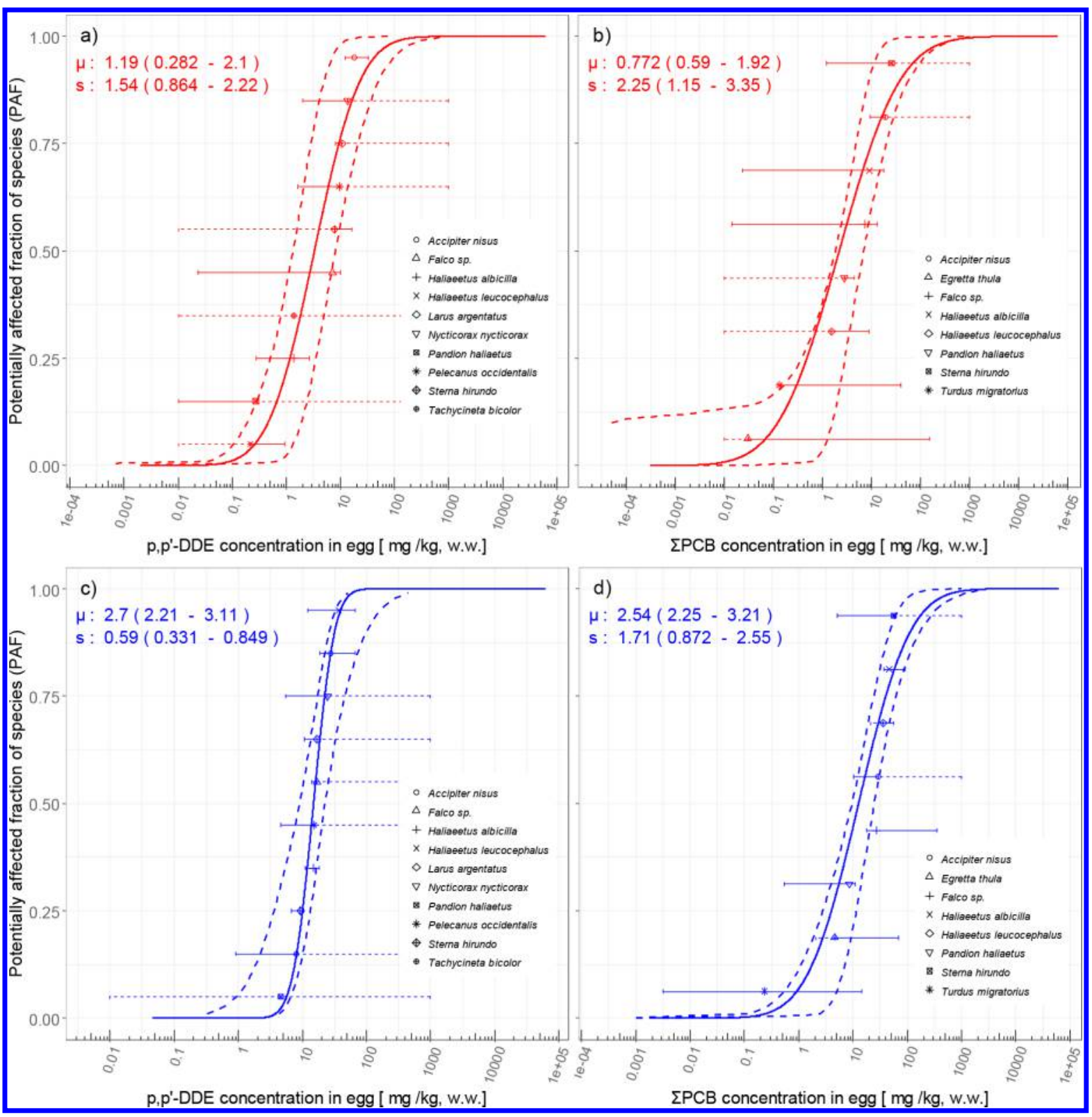

Figure 3. Species sensitivity distributions for derived from field-based $\mathrm{EC}_{10} \mathrm{~s}$ (in red) and $\mathrm{EC}_{50} \mathrm{~s}$ (in blue) for $p, p^{\prime}-\mathrm{DDE}(\mathrm{a}, \mathrm{c})$ and $\Sigma \mathrm{PCB}$ (b, d), respectively. Error bars around each $\mathrm{EC}_{10 / 50}$ point indicate its $95 \%$ confidence intervals (dashed error bars indicate infinite confidence intervals). $95 \%$ confidence intervals corresponding to the derived SSDs are indicated as dashed lines. Additionally, the natural log-transformed $\mu$ and $\sigma$ (s) per SSD was given (95\% confidence interval between brackets).

moist percentage, respectively. The specific composition of PCB congeners included in $\Sigma$ PCBs is listed per source in Table S2 of the Supporting Information.

Weights. The data set used in this study consists of both data obtained from single nests, as well as averaged bird productivity and egg residue concentrations, encompassing multiple nests, years, or locations. Therefore, in order for a larger sample size to yield a large influence on the analysis, the data points relating toxicant concentrations in eggs to reproductive success were weighted according to eq 8

$$
w_{i}=\frac{1}{\frac{1}{N_{\text {nests }}}+\frac{1}{N_{\text {eggs }}}}
$$

where $w_{i}$ defines the weighting factor corresponding to data point $i, N_{\text {eggs }}$ refers to the number of sampled eggs per toxicant data record, and $N_{\text {nests }}$ refers to the number of active nests per productivity data record. With eq 8 , we valued the information required for the productivity (based on the number of nests sampled) and chemical residues (based on the number of analyzed eggs) equally. This means that the weights are limited by the smallest sample size.

Exposure Data Associated with Ecological Risk. Additional data describing contaminant concentrations in bird's eggs used in calculating ecological risks by $p, p^{\prime}$-DDE and PCBs were obtained using the Web of Knowledge in searches combining the terms egg residues, birds, and multiple specific areas. This search resulted in contamination data for two distinct areas (the Arctic $^{87-101}$ and the American Great Lakes ${ }^{102-110}$ ). Single toxicant exposure data were natural log-transformed and used to construct a probability density distribution that was applied in the calculation of ecological risks. Exposure data were 


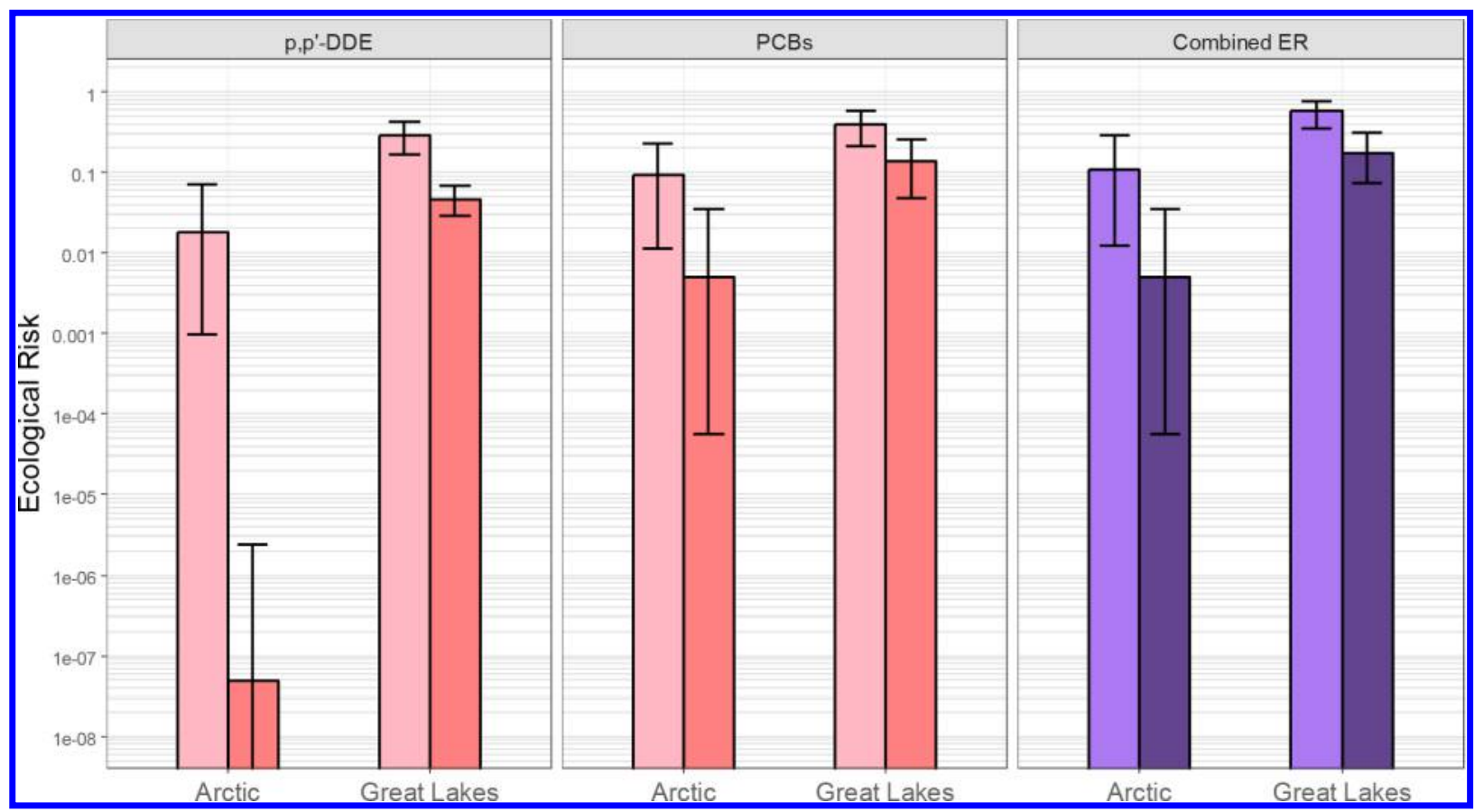

Figure 4. Ecological risks [fraction] with corresponding 95\% confidence intervals in the Arctic and the Great lakes for PCBs, p,p-DDE, and their combined risk, based on bird $\mathrm{EC}_{10} \mathrm{~s}$ (light) and $\mathrm{EC}_{50} \mathrm{~s}$ (dark).

included without further weighting of number of eggs and nests.

\section{RESULTS}

Quantile Exposure-Response Curves. Quantile exposure-response curves, set at the 95th percentile, were fitted for $12\left(p, p^{\prime}-\mathrm{DDE}\right)$ and $14(\Sigma \mathrm{PCBs})$ raptorial, piscivorous, and insectivorous bird species for the two compounds as exemplified in Figure 2 for Haliaeetus albicilla. We derived 26 exposure-responses, as for 4 out of 15 species we only found sufficient data to include one of the two POPs concerned (see Figure S1 $\left(p, p^{\prime}-\mathrm{DDE}\right)$ and Figure S2 ( $\left.\Sigma \mathrm{PCBs}\right)$ in the SI). Excluding species-substance combinations that were not considered sufficiently consistent with the other quantiles resulted in 18 exposure-response curves covering 12 species (see Figures S3 $\left(\mathrm{EC}_{50} \mathrm{~s}\right)$ and $\mathrm{S} 4\left(\mathrm{EC}_{10} \mathrm{~s}\right)$ in the SI).

A significant decrease of reproductive success in birds along increasing toxicant gradients was observed for both compounds for exposure-response curves set at the 95th percentile. $\mathrm{EC}_{50} \mathrm{~s}$ ranged from $4.58 \mathrm{mg} / \mathrm{kg}$ egg w.w. (Pandion haliaetus) to 37 $\mathrm{mg} / \mathrm{kg}$ (Haliaeetus leucocephalus) for $p, p^{\prime}$-DDE and from 4.62 $\mathrm{mg} / \mathrm{kg}$ (Egretta thula) to $124 \mathrm{mg} / \mathrm{kg}$ (Larus argentatus) for $\Sigma$ PCBs. $\mathrm{EC}_{10} \mathrm{~s}$ ranged from $0.2 \mathrm{mg} / \mathrm{kg}$ (Haliaeetus leucocephalus) to $17.7 \mathrm{mg} / \mathrm{kg}$ (Accipiter nisus) for $p, p^{\prime}-\mathrm{DDE}$ and from 0.03 $\mathrm{mg} / \mathrm{kg}$ (Egretta thula) to $83 \mathrm{mg} / \mathrm{kg}$ (Pandion haliaetus) for ¿PCBs (Table 1).

Species Sensitivity Distributions. SSD models were derived from the field-based effect concentrations for the two contaminants, based on 18 quantile exposure-response curves set at the 95th percentile. As the quantile regression estimates in some cases provide zero or infinite $\mathrm{EC}_{50^{-}}$or $\mathrm{EC}_{10^{-}}$values due to the large statistical uncertainties involved, not all 10,000 realizations of the SSD curves yielded numerical results. For $p, p^{\prime}$-DDE, only $9-13 \%$ of the iterations resulted in a numerical mean $(\mu)$ and standard deviation $(\sigma)$ of the SSD, while for $\Sigma \mathrm{PCB}$ this percentage was higher with $32-37 \%$ of the iterations. This most likely results in an underestimation of the uncertainty bounds of the SSDs, as presented in Figure 3. Average toxicity $\left(\mathrm{e}^{\mu}\right)$ based on $\mathrm{EC}_{50} \mathrm{~s}$ and $\mathrm{EC}_{10} \mathrm{~s}$ derived for $p, p^{\prime}$-DDE is $14.9 \mathrm{mg} / \mathrm{kg}$ egg w.w. (9.1-22.4) and $3.3 \mathrm{mg} / \mathrm{kg}$ (2.9-8.2), respectively. Average toxicity associated with $\Sigma \mathrm{PCB}$ contamination is $12.7 \mathrm{mg} / \mathrm{kg}$ egg w.w. (9.5-24.8) and $2.2 \mathrm{mg} /$ $\mathrm{kg}(2.1-6.8)$ based on $\mathrm{EC}_{50} \mathrm{~s}$ and $\mathrm{EC}_{10} \mathrm{~s}$, respectively.

Ecological Risks. Single toxicant ERs calculated for the two compounds separately were a factor of $16\left(p, p^{\prime}-\mathrm{DDE}\right)$ to 4.3 ( $\Sigma$ PCBs) higher in the North American Great Lakes compared to Arctic regions, based on $10 \%$ response levels. Individual ERs for $p, p^{\prime}$-DDE based on $50 \%$ response levels were 5 orders of magnitude $\left(p, p^{\prime}\right.$-DDE) higher in North American Great Lakes than in Arctic regions, while individual ERs for $\Sigma$ PCBs were a factor of 27 higher in North American Great Lakes than in Arctic regions. Consequently, differences in the overall combined $\mathrm{ER}_{10} \mathrm{~s}$ calculated for the American Great Lakes and Arctic sites were shown to be statistically significant, calculating higher combined $\mathrm{ER}_{10} \mathrm{~s}$ for the American Great Lakes compared to Arctic sites $\left(5.7 \times 10^{-1}\right.$ vs $1.1 \times 10^{-1}$, respectively). The same holds for the combined $\mathrm{ER}_{50} \mathrm{~s}(1.7 \times$ $10^{-1}$ vs $\left.4.9 \times 10^{-3}\right)$. PCB-contamination contributed most to combined ERs in the American Great Lake District and the Arctic based on both $\mathrm{ER}_{10} \mathrm{~s}$ and $\mathrm{ER}_{50} \mathrm{~s}$ (Figure 4).

Of all the Great Lakes, the highest combined $\mathrm{ER}_{10}$ and $\mathrm{ER}_{50}$ were calculated for Lake Ontario $\left(6.3 \times 10^{-1}\right.$ and $2.2 \times 10^{-1}$, respectively). In the Arctic region, the highest combined $\mathrm{ER}_{10} \mathrm{~S}$ and $\mathrm{ER}_{50} \mathrm{~s}$ were calculated for the Barents Sea $\left(1.23 \times 10^{-1}\right.$ and $5.4 \times 10^{-3}$, respectively), Norton Sound $\left(1.31 \times 10^{-1}\right.$ and $9.6 \times$ $\left.10^{-3}\right)$, and Bering Sea $\left(1.2 \times 10^{-1}\right.$ and $\left.7.42 \times 10^{-3}\right)($ see Table S5 in the Supporting Information).

\section{DISCUSSION}

Our study explained how field data can be used to systemically derive chemical-specific and combined ecological risks. We also showed how the method can be applied in practice for $p, p^{\prime}$ - 
DDE and $\Sigma$ PCBs in the Arctic and the American Great Lakes. Below, we discuss the three key elements of our study, i.e. the derivation of exposure-response curves, species sensitivity distributions, and ecological risks, respectively.

Exposure-Response Curves. In the present study, we derived exposure-response curves for multiple piscivorous, raptorial, and insectivorous bird species, relating $p, p^{\prime}-\mathrm{DDE}$ and $\Sigma \mathrm{PCB}$ in eggs to reproductive success, based on field data. $\mathrm{EC}_{50} \mathrm{~s}$ obtained in this study were higher compared to fieldbased $\mathrm{EC}_{50} \mathrm{~s}$ calculated for the same bird species from other studies, ${ }^{45,111-113}$ likely due to the fact that other field studies use traditional regression approaches that focus on mean effects. ${ }^{14}$ Our exposure-response curves were fitted along the upper boundary of the response's distribution, resulting in higher $\mathrm{EC}_{50} \mathrm{~s}$. Effect concentrations calculated using traditional regression analysis $(\tau=0.50$; Table S3 in the Supporting Information) in the present study were similar to (for Falco sp., ${ }^{111}$ Pelecanus occidentalis, ${ }^{113}$ and Pandion haliaetus ${ }^{113}$ ) or lower (for Haliaeetus albicilla/leucocephalus ${ }^{12}$ ) than those derived in other field studies.

It should be noted, however, that our exposure-response curves resulted in excluding 6 out of 14 species for $\Sigma$ PCB and 2 out of 12 species for $p, p^{\prime}$-DDE due to inconsistencies with lower quantile estimates. We also obtained very large uncertainty intervals for a number of species, depending on the number and distribution of the field-based exposure response data. These uncertainties were further propagated to the SSDs and ERs. We were, however, not able to fully quantify the uncertainty intervals of the SSDs and ERs, as not all simulations converged to a numerical outcome. This finding emphasizes the importance of having sufficient and welldistributed field data to reliably perform quantile regression analysis.

Species Sensitivity Distributions. Typically, the utility of SSD models to predict toxicity effects on the ecosystem level depends on a number of assumptions. ${ }^{114}$ First, it is typically assumed that a log-normal distribution describes species sensitivities toward a certain chemical ${ }^{4}$ and that including ten or more species is preferable to obtain representative SSDs. ${ }^{28}$ In our case, the toxicity data were indeed lognormally distributed, while the number of species included was eight to ten. Another important assumption is that species selection is unbiased and fully represents the differences in sensitivity toward a chemical. ${ }^{4}$ In the present study, SSDs were based on raptorial, piscivorous, and insectivorous bird species, covering multiple taxonomic groups. Differences in sensitivity of bird species to dioxin-like compounds, such as certain PCB congeners, are, however, explained by differences in the aryl hydrocarbon receptor 1 ligand-binding domain (AHR1-LB) and not so much by food sources (see Table $S 6$ in the Supporting Information). In the present study, Larus argentatus and Sterna hirundo were identified as the species with the highest $\mathrm{EC}_{50}$ for $\mathrm{EPCBs}$, followed by Haliaeetus species and Falco sp.. These findings correspond with the classification of Farmahin et al., ${ }^{115}$ who indicated that these birds are insensitive to dioxin-like compounds. The species with the highest sensitivity toward $\mathrm{XPCB}$ in our study was the insectivorous bird Turdus migratorius. Farmahin et al. ${ }^{115}$ classified this bird as semisensitive to dioxin-like compounds. Other birds classified as semisensitive were Tachycineta bicolor, Troglodytes aedon, and Phalacrocorax sp. Although experimental studies focusing on the reproductive effects of PCB residues in eggs have been performed on species classified as highly sensitive (e.g.,
European starling (Sturnus vulgaris) or the gray catbird (Dumetella carolinensis)), ${ }^{116,117}$ field monitoring data on these species was grossly lacking. This implies that our SSDs most likely underestimate the effects of dioxin-like PCBs toward birds.

Ecological Risks. Ecological risks were significantly higher in the North American Great Lakes compared to the Arctic region. This is most likely due to the high number of pollutant point sources located along the Niagara and Detroit Rivers and the massive storage of organochlorine compounds in lake sediments that are re-emitted into the water column and subsequently accumulate in the food chain. ${ }^{118,119}$ Note, however, that the calculated ecological risks for the American Great Lakes do not necessarily cover the trophic levels evenly, as in this area we found egg residue data encompassing a limited set of species, covering mainly Tachycineta bicolor and Larus argentatus.

Contamination with $\mathrm{PCBs}$ contributed highly to our calculated combined ERs in both areas. While the field-based average toxicity and spread between the species is rather similar for the two chemicals included in our study, systematically higher $\Sigma$ PCBs concentrations were reported in the field compared to $p, p^{\prime}$-DDE. Within the Arctic region, the high relative ecological risk (and thus combined ER) caused by PCB-contamination is most likely due to point sources from landfill, drilling rigs, harbors, and urban areas in Alaska (Bering Sea and Norton Sound) and Northern Norway (Barents Sea). ${ }^{120}$ ERs calculated in other Arctic areas were relatively low, possibly due to geographical remoteness and the lower anthropogenic stress that is associated with this. The relatively high combined ERs for the Great Lakes were due to high individual ERs related to both $\mathrm{PCB}$ and $p, p^{\prime}$-DDE contamination. The highest combined ER in the American Great Lake area was calculated for Lake Ontario, most likely caused by intensive farming in its catchment basin, ${ }^{121}$ followed by Lake Erie and Lake Huron. These findings are in line with conclusions drawn in previous studies focusing on chemical residues in sediment, surface water, and fish, indicating Lake Ontario as most contaminated. ${ }^{122,123}$ Obviously, risks may be different for individual bird species in other areas or specific locations within the Arctic and Great Lakes, depending on the actual concentrations present and the sensitivity of the species. For instance, effects on Pelecanus occidentalis in South Carolina and Phalacrocorax auritus in Green Bay were associated with $p, p^{\prime}$-DDE rather than PCBs. ${ }^{124,125}$ By contrast, in Dutch colonies, multiple studies suggest that Phalacrocorax carbo sinensis survival and reproduction and subsequent population development could partly be explained by PCB concentrations. $^{71,126}$

Relevancy. SSDs are typically derived using data obtained from laboratory experiments, including only a limited number of species. ${ }^{15,116,127}$ The present study illustrates how bird species monitoring data can be used to derive field-based SSDs. Although field-based SSDs are used before in ecotoxicology, ${ }^{5,127,128}$ to our knowledge this study is the first to derive SSDs for piscivorous, raptorial, and insectivorous bird species that include effect concentrations obtained through quantile regression analysis that reduces bias associated with extraneous variables. SSDs derived from field monitoring data are considered more ecologically relevant. The use of field data is recommended by the U.S. Environmental Protection Agency Science Advisory Board for the derivation of ecological risks of chemicals. ${ }^{129}$ This study demonstrates that the field-based 
approach can be applied to calculate ecological risks by combining SSDs with measured environmental POP concentrations.

\section{ASSOCIATED CONTENT}

\section{S Supporting Information}

The Supporting Information is available free of charge on the ACS Publications website at DOI: 10.1021/acs.est.7b05904.

Figures $S 1$ and S2, exposure-response curves obtained for $p, p^{\prime}$-DDE and $\Sigma$ PCBs at $\tau=0.95$; Table S1, all maximum productivity values per species; Table S2, all PCB congeners used in the derivation of the exposureresponse curves and the exposure concentration distribution for $\Sigma$ PCBs listed per reference; Figures S3 and S4, all modeled effect concentrations at the $\tau=0.95$ and the three additional quantiles $(\tau=0.25, \tau=0.5, \tau=$ 0.75) for $\mathrm{EC}_{10}$ and $\mathrm{EC}_{50}$, respectively; Table $\mathrm{S} 3, \mathrm{EC}_{10} \mathrm{~S}$ and $\mathrm{EC}_{50} \mathrm{~s}$ associated with traditional exposure-response curves $(\tau=0.5$ and their $95 \%$ confidence intervals; Table $S 4$, mean and standard deviations of $\log _{10}$-transformed egg concentrations found in the American Great Lake area and the Arctic used in calculating ERs; Table S5, all calculated $\mathrm{ER}_{10} \mathrm{~s}, \mathrm{ER}_{50} \mathrm{~s}$, and combined ERs per subregion; Table S6, all subtypes of AHR1-LB domains explaining sensitivity toward dioxin-like compounds of bird species used in this study (PDF)

$\mathrm{R}$-code used in the construction of the quantile exposureresponse curves (TXT)

Raw data that relates chemical contamination in egg residues to the productivity of bird species (XLSX)

\section{AUTHOR INFORMATION}

\section{Corresponding Author}

*Phone: +31-(0)24-365 23 93. E-mail: R.Hoondert@science. ru.nl.

\section{ORCID $\odot$}

Renske P. J. Hoondert: 0000-0001-6990-9851

\section{Notes}

The authors declare no competing financial interest.

\section{ACKNOWLEDGMENTS}

We would like to thank three anonymous reviewers for their useful comments on the earlier draft of this manuscript. This research project was funded by The Netherlands Organisation for Scientific Research (NWO), under The Netherlands Polar Programme (NPP), Project No.: 866.13.007.

\section{REFERENCES}

(1) Sánchez-Bayo, F.; Tennekes, H. A. Environmental risk assessment of agrochemicals - A critical appraisal of current approaches. In Toxicity and Hazard of Agrochemicals; 2015; p 1, DOI: 10.5772/60739. (2) OECD Report of the OECD workshop on the extrapolation of laboratory aquatic toxicity data to the real environment; 1990.

(3) Newman, M. C.; Ownby, D. R.; Mezin, L. C.; Powell, D. C.; Christensen, T. R.; Lerberg, S. B.; Anderson, B. A. Applying speciessensitivity distributions in ecological risk assessment: Assumptions of distribution type and sufficient numbers of species. Environ. Toxicol. Chem. 2000, 19 (2), 508-515.

(4) Posthuma, L.; Suter, G. W., II; Traas, T. P. Species sensitivity distributions in ecotoxicology; Lewis Publishers - CRC Press: 2002.

(5) Azevedo, L. B.; De Schryver, A. M.; Hendriks, A. J.; Huijbregts, M. A. Calcifying species sensitivity distributions for ocean acidification. Environ. Sci. Technol. 2015, 49 (3), 1495-1500.
(6) Aldenberg, T.; Jaworska, J. S.; Traas, T. P. Normal species sensitivity distributions and probabilistic ecological risk assessment. In Species Sensitivity Distributions in Ecotoxicology; Posthuma, L., Suter, G. W., II, Traas, T. P., Eds.; Lewis Publishers: 2002; DOI: 10.1201/ 9781420032314.ch5.

(7) Korsman, J. C.; Schipper, A. M.; Hendriks, A. J. Dietary toxicity thresholds and ecological risks for birds and mammals based on species sensitivity distributions. Environ. Sci. Technol. 2016, 50 (19), 10644-10652.

(8) Pacheco, M. A. W.; McIntyre, D. O.; Linton, T. K. Integrating chemical and biological criteria. Environ. Toxicol. Chem. 2005, 24 (11), 2983-2991.

(9) Calow, P.; Forbes, V. E. Does ecotoxicology inform ecological risk assessment? Environ. Sci. Technol. 2003, 37 (7), 146A-151A.

(10) Moriarty, F. Ecotoxicology. Hum. Toxicol. 1988, 7 (5), 437441.

(11) Duboudin, C.; Ciffroy, P.; Magaud, H. Effects of data manipulation and statistical methods on species sensitivity distributions. Environ. Toxicol. Chem. 2004, 23 (2), 489-499.

(12) Yang, J.; Zhang, X.; Xie, Y.; Song, C.; Sun, J.; Zhang, Y.; Giesy, J. P.; Yu, H. Ecogenomics of Zooplankton Community Reveals Ecological Threshold of Ammonia Nitrogen. Environ. Sci. Technol. 2017, 51 (5), 3057-3064.

(13) Hendriks, A. J. How to deal with $100,000+$ substances, sites, and species: Overarching principles in environmental risk assessment. Environ. Sci. Technol. 2013, 47, 3546-3547.

(14) Suter, G. Analysis of laboratory and field studies of reproductive toxicity in birds exposed to dioxin-like compounds for use in ecological risk assessment; EPA/600/R-03: 2003.

(15) van Goethem, T. M.; Huijbregts, M. A.; Wamelink, G. W.; Schipper, A. M. How to assess species richness along single environmental gradients? Implications of potential versus realized species distributions. Environ. Pollut. 2015, 200, 120-125.

(16) Cade, B. S.; Noon, B. R. A gentle introduction to quantile regression for ecologists. Front. Ecol. Environ. 2003, 1 (8), 412-420.

(17) Newton, I.; Bogan, J. The role of different organochlorine compounds in the breeding of British sparrowhawks. I. Appl. Ecol. 1978, 15 (1), 105-116.

(18) Carson, R. Silent Spring; Houghton Mifflin: 1962.

(19) Fry, D. M. Reproductive effects in birds exposed to pesticides and industrial chemicals. Environ. Health Perspect. 1995, 103 (Suppl 7), 165 .

(20) Fox, G. A.; Gilman, A.; Peakall, D.; Anderka, F. Behavioral abnormalities of nesting Lake Ontario herring gulls. I. Wildl. Manage. 1978, 42 (3), 477-483.

(21) Koenker, R. quantreg: Quantile Regression. R package version 5.05; R Foundation for Statistical Computing: Vienna, 2013. Available at http://CRAN.R-project.org/package=quantreg (accessed Feb 28, 2018).

(22) Gadagkar, S. R.; Call, G. B. Computational tools for fitting the Hill equation to dose-response curves. L. Pharmacol. Toxicol. Methods 2015, 71, 68-76.

(23) Hill, A. V. The possible effects of the aggregation of the molecules of haemoglobin on its dissociation curves. J. Physiol. 1910, 40, 4-7.

(24) Rider, C. V.; LeBlanc, G. A. An integrated addition and interaction model for assessing toxicity of chemical mixtures. Toxicol. Sci. 2005, 87 (2), 520-528.

(25) Bottai, M.; Cai, B.; McKeown, R. E. Logistic quantile regression for bounded outcomes. Stat. Med. 2010, 29 (2), 309-317.

(26) Beasley, A.; Belanger, S. E.; Brill, J.; Otter, R. Evaluation and comparison of the relationship between NOEC and EC10 or EC20 values in chronic Daphnia toxicity testing. Environ. Toxicol. Chem. 2015, 34 (10), 2378-2384.

(27) Koenker, R. Quantile Regression in R: a Vignette; 2015. URL: https://cran.r-project.org/web/packages/quantreg/vignettes/rq.pdf (accessed Feb 28, 2018). 
(28) Wheeler, J.; Grist, E.; Leung, K.; Morritt, D.; Crane, M. Species sensitivity distributions: data and model choice. Mar. Pollut. Bull. 2002, 45 (1), 192-202.

(29) Aldenberg, T.; Rorije, E. Species sensitivity distribution estimation from uncertain (QSAR-based) effects data. ATLA 2013, 41 (1), 19-31.

(30) Newton, I.; Bogan, J.; Rothery, P. Trends and effects of organochlorine compounds in sparrowhawk eggs. I. Appl. Ecol. 1986, 23 (2), 461-478.

(31) Newton, I.; Wyllie, I. Recovery of a sparrowhawk population in relation to declining pesticide contamination. I. Appl. Ecol. 1992, 29 (2), 476-484.

(32) Hothem, R. L.; Marois, K. C.; Wainwright, S. E.; Roster, D. L.; King, K. A.; Keldsen, T. J. Spatial and temporal trends of contaminants in eggs of wading birds from San Francisco Bay, California. Environ. Toxicol. Chem. 1995, 14 (8), 1319-1331.

(33) Findholt, S. L. Organochlorine residues, eggshell thickness, and reproductive success of snowy egrets nesting in Idaho. Condor 1984, $86,163-169$.

(34) Henny, C. J.; Blus, L. J.; Hulse, C. S. Trends and effects of organochlorine residues on Oregon and Nevada wading birds, 197983. Col. Waterbird. 1985, 8 (2), 117-128.

(35) Ambrose, R. E.; Matz, A. C.; Swem, T.; Bente, P. J. Technical report: Environmental contaminants in American and Arctic peregrine falcon eggs in Alaska, 1979-95; U. S. Fish and Wildlife Service, Department of the Interior: 2000.

(36) Ambrose, S.; Florian, C.; Ritchie, R. J.; Payer, D.; O’brien, R. M. Recovery of American peregrine falcons along the upper Yukon River, Alaska. I. Wildl. Manage. 2016, 80 (4), 609-620.

(37) Frakes, R. A.; Lemieux, S. L. Reproductive success and egg contaminant concentrations of southern New Jersey peregrine falcons; U.S. Fish and Wildlife Service and New Jersey Division of Fish, Game and Wildlife: 1998.

(38) Kane, C. M.; Zhao, Y.; Clark, K. E. Organochlorine pesticides, PCBs, dioxins and metals in post-term peregrine falcon (Falco peregrinus) eggs from the Mid-Atlantic states: New Yersey, Pensylvania, Delaware, Maryland and Virginia - 1993-1999; U. S. Fish and Wildlife Service: 2004.

(39) Hebert, C.; Weseloh, D.; Kot, L.; Glooschenko, V. Organochlorine contaminants in a terrestrial foodweb on the Niagara Peninsula, Ontario, Canada 1987-89. Arch. Environ. Contam. Toxicol. 1994, 26 (3), 356-366.

(40) Helander, B.; Olsson, A.; Bignert, A.; Asplund, L.; Litzén, K. The role of DDE, PCB, coplanar PCB and eggshell parameters for reproduction in the white-tailed sea eagle (Haliaeetus albicilla) in Sweden. Ambio 2002, 31 (5), 386-403.

(41) Bignert, A.; Helander, B. O. Monitoring of contaminants and their effects on the common Guillemot and the White-tailed sea eagle. I. Ornithol. 2015, 156 (1), 173-185.

(42) Nordlöf, U.; Helander, B.; Zebühr, Y.; Bignert, A.; Asplund, L. Polychlorinated dibenzo-p-dioxins, polychlorinated dibenzofurans and non-ortho-PCBs in eggs of white-tailed sea eagles collected along the Swedish coast in the Baltic Sea. Sci. Total Environ. 2012, 438, 166173.

(43) Helander, B.; Olsson, M.; Reutergårdh, L. Residue levels of organochlorine and mercury compounds in unhatched eggs and the relationships to breeding success in white-tailed sea eagles Haliaeetus albicilla in Sweden. Ecography 1982, 5 (4), 349-366.

(44) Mahaffy, M.; Ament, K.; McMillan, A.; Tillit, D. Environmental contaminants in bald eagles nesting in Hood Canal, Washington, 19921997; 2001; pp 13410-1130.

(45) Best, D. A.; Elliott, K. H.; Bowerman, W. W.; Shieldcastle, M.; Postupalsky, S.; Kubiak, T. J.; Tillitt, D. E.; Elliott, J. E. Productivity, embryo and eggshell characteristics, and contaminants in bald eagles from the Great Lakes, USA, 1986 to 2000. Environ. Toxicol. Chem. 2010, 29 (7), 1581-1592.

(46) Grier, J. W. Ban of DDT and subsequent recovery of reproduction in bald eagles. Science 1982, 218 (4578), 1232-1235.
(47) Ewins, P. J.; Weseloh, D.; Mineau, P. Geographical distribution of contaminants and productivity measures of herring gulls in the Great Lakes: Lake Huron 1980. L. Great Lakes Res. 1992, 18 (2), 316330

(48) Peakall, D. B.; Fox, G. A. Toxicological investigations of pollutant-related effects in Great Lakes gulls. Environ. Health Perspect. 1987, 71, 187-193.

(49) Weseloh, JD. V.; Mineau, P.; Struger, J. Geographical distribution of contaminants and productivity measures of herring gulls in the Great Lakes: Lake Erie and connecting channels 1978/79. Sci. Total Environ. 1990, 91, 141-159.

(50) Weseloh, D. V. C.; Ewins, P. J.; Struger, J.; Mineau, P.; Norstrom, R. J. Geographical distribution of organochlorine contaminants and reproductive parameters in herring gulls on Lake Superior in 1983. Environ. Monit. Assess. 1994, 29 (3), 229-251.

(51) Blus, L.; Rattner, B.; Melancon, M.; Henny, C. Reproduction of black-crowned night-herons related to predation and contaminants. Pacific Seabirds 1996, 23 (1), 24.

(52) Custer, T. W.; Hensler, G. L.; Kaiser, T. E. Clutch size, reproductive success, and organochlorine contaminants in Atlantic coast black-crowned night-herons. Auk 1983, 100 (3), 699-710.

(53) Hothem, R. L.; Hatch, D. Reproductive Success of the Blackcrowned Night Heron at Alcatraz Island, San Francisco Bay, California, 1990-2002. Waterbirds 2004, 27 (1), 112-125.

(54) Rattner, B.; McGowan, P.; Hatfield, J.; Hong, C.-S.; Chu, S. Organochlorine Contaminant Exposure and Reproductive Success of Black-Crowned Night-Herons (Nycticorax nycticorax) Nesting inBaltimore Harbor, Marvland. Arch. Environ. Contam. Toxicol. 2001, 41 (1), 73-82.

(55) Wainwright, S.E.; Mora, M.; Sericano, J.; Thomas, P. Chlorinated hydrocarbons and biomarkers of exposure in wading birds and fish of the Lower Rio Grande Valley, Texas. Arch. Environ. Contam. Toxicol. 2001, 40 (1), 101-111.

(56) Henny, C. J.; Blus, L. J.; Krynitsky, A. J.; Bunck, C. M. Current impact of DDE on black-crowned night-herons in the intermountain west. I. Wildl. Manage. 1984, 48 (1), 1-13.

(57) Buck, J.; Kaiser, J. Contaminant concentrations in osprey (Pandion haliaetus) eggs from portland harbor and surrounding areas: Data summary report; U. S. Fish and Wildlife Services and Kaiser and Associates Environmental Consulting, LLC: 2011; p 23.

(58) Lazarus, R. S.; Rattner, B. A.; McGowan, P. C.; Hale, R. C.; Schultz, S. L.; Karouna-Renier, N. K.; Ottinger, M. A. Decadal reevaluation of contaminant exposure and productivity of ospreys (Pandion haliaetus) nesting in Chesapeake Bay Regions of Concern. Environ. Pollut. 2015, 205, 278-290.

(59) Martin, P. A.; De Solla, S. R.; Ewins, P. Chlorinated hydrocarbon contamination in osprey eggs and nestlings from the Canadian Great Lakes Basin, 1991-1995. Ecotoxicology 2003, 12 (14), 209-224.

(60) Morrissey, C.; Kardosi, G.; Wilson, L.; Elliott, J. Effect of food supply and contaminants on osprey productivity in southern British Columbia, Canada. Raptors worldwide. World Working Group on Birds of Prey and Owls, Budapest, Hungary 2004, 1, 353-368.

(61) Rattner, B.; McGowan, P.; Golden, N.; Hatfield, J.; Toschik, P.; Lukei, R., Jr; Hale, R.; Schmitz-Afonso, I.; Rice, C. Contaminant exposure and reproductive success of ospreys (Pandion haliaetus) nesting in Chesapeake Bay regions of concern. Arch. Environ. Contam. Toxicol. 2004, 47 (1), 126-140.

(62) Steidl, R. J.; Griffin, C. R.; Niles, L. J. Contaminant levels of osprey eggs and prey reflect regional differences in reproductive success. I. Wildl. Manage. 1991, 55 (4), 601-608.

(63) Toschik, P. C.; Rattner, B. A.; McGowan, P. C.; Christman, M. C.; Carter, D. B.; Hale, R. C.; Matson, C. W.; Ottinger, M. A. Effects of contaminant exposure on reproductive success of ospreys (Pandion haliaetus) nesting in Delaware River and Bay, USA. Environ. Toxicol. Chem. 2005, 24 (3), 617-628.

(64) Johnson, B. L.; Henny, C. J.; Kaiser, J. L.; Davis, J. W.; Schultz, E. P. Assessment of contaminant exposure and effects on ospreys nesting 
along the Lower Duwamish River, Washington, 2006-07; U.S. Department of the Interior and U.S. Geological Survey: 2009.

(65) Henny, C.; Grove, R.; Kaiser, J. Osprey distribution, abundance, reproductive success and contaminant burdens along lower Columbia River, 1997/1998 versus 2004. Arch. Environ. Contam. Toxicol. 2008, 54 (3), 525-534.

(66) Lazarus, R. S.; Rattner, B. A.; McGowan, P. C.; Hale, R. C.; Karouna-Renier, N. K.; Erickson, R. A.; Ottinger, M. A. Chesapeake Bay fish-osprey (Pandion haliaetus) food chain: Evaluation of contaminant exposure and genetic damage. Environ. Toxicol. Chem. 2016, 35 (6), 1560-1575.

(67) Anderson, D. W.; Jehl, J.; Risebrough, R. W.; Woods, L. A.; Deweese, L. R.; Edgecomb, W. G. Brown pelicans: improved reproduction off the southern California coast. Science 1975, 190 (4216), 806-808.

(68) King, K. A.; Blankinship, D. R.; Payne, E.; Krynitsky, A. J.; Hensler, G. L. Brown pelican populations and pollutants in Texas 1975-1981. Wilson Bull. 1985, 97 (2), 201-214.

(69) Blus, L.; Cromartie, E.; McNease, L.; Joanen, T. Brown pelican: population status, reproductive success, and organochlorine residues in Louisiana, 1971-1976. Bull. Environ. Contam. Toxicol. 1979, 22 (1), $128-134$.

(70) Harris, M. L.; Wilson, L. K.; Elliott, J. E. An assessment of PCBs and OC pesticides in eggs of double-crested (Phalacrocorax auritus) and pelagic (P. pelagicus) cormorants from the west coast of Canada, 1970 to 2002. Ecotoxicology 2005, 14 (6), 607-625.

(71) Dirksen, S.; Boudewijn, T.; Slager, L.; Mes, R.; Van Schaick, M.; De Voogt, P. Reduced breeding success of cormorants (Phalacrocorax carbo sinensis) in relation to persistent organochlorine pollution of aquatic habitats in the Netherlands. Environ. Pollut. 1995, 88 (2), 119132.

(72) Giesy, J. P.; Ludwig, J. P.; Tillitt, D. E. Dioxins, dibenzofurans, PCBs and colonial, fish-eating water birds. In Dioxins and Health; Springer: 1994; pp 249-307, DOI: 10.1007/978-1-4899-1462-0_9.

(73) White, D. H.; Mitchell, C. A.; Swineford, D. M. Reproductive success of black skimmers in Texas relative to environmental pollutants. J. Field Ornithol. 1984, 55 (1), 18-30.

(74) King, K. A.; Krynitsky, A. J. Population trends, reproductive success, and organochlorine chemical contaminants in waterbirds nesting in Galveston Bay. Arch. Environ. Contam. Toxicol. 1986, 15 (4), 367-376.

(75) Morris, R. D.; Hunter, R. A.; McElman, J. F. Factors affecting the reproductive success of Common Tern (Sterna hirundo) colonies on the lower Great Lakes during the summer of 1972. Can. I. Zool. 1976, 54 (11), 1850-1862.

(76) Murk, A.; Boudewijn, T.; Meininger, P.; Bosveld, A.; Rossaert, G.; Ysebaert, T.; Meire, P.; Dirksen, S. Effects of polyhalogenated aromatic hydrocarbons and related contaminants on common tern reproduction: integration of biological, biochemical, and chemical data. Arch. Environ. Contam. Toxicol. 1996, 31 (1), 128-140.

(77) Cifuentes, J. M.; Becker, P. H. Contaminants in bird eggs in the Wadden Sea: Effects of environmental chemicals on reproductive success and mass growth of seabirds at the Wadden Sea in the mid 1990s; Common Wadden Sea Secretariat (CWSS): 2004.

(78) Soucek, D. J.; Levengood, J. M.; Gallo, S.; Hill, W. R.; Bordson, G. O.; Talbott, J. L. Risks to birds in the lake calumet region from contaminated emergent aquatic insects; Illinois Sustainable Technology Center: Champaign, IL, 2013.

(79) Bishop, C. A.; Mahony, N. A.; Trudeau, S.; Pettit, K. E. Reproductive success and biochemical effects in tree swallows (Tachycineta bicolor) exposed to chlorinated hydrocarbon contaminants in wetlands of the Great Lakes and St. Lawrence River Basin, USA and Canada. Environ. Toxicol. Chem. 1999, 18 (2), 263-271.

(80) Bonier, F. A meta-analysis of relationships between polychlorinated biphenyl exposure and performance across studies of free-

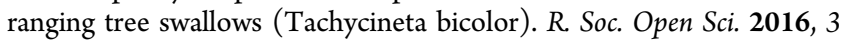
(4), 150634.

(81) Elliott, J.; Martin, P.; Arnold, T.; Sinclair, P. Organochlorines and reproductive success of birds in orchard and non-orchard areas of central British Columbia, Canada, 1990-91. Arch. Environ. Contam. Toxicol. 1994, 26 (4), 435-443.

(82) Newsted, J. L.; Blankenship, A. L.; Jones, P. D.; Giesy, J. P.; Neigh, A. M.; Zwiernik, M. J.; MacCarroll, M. A.; Kay, D. P. Productivity of tree swallows (Tachycineta bicolor) exposed to PCBs at the Kalamazoo River Superfund Site. I. Toxicol. Environ. Health, Part A 2006, 69 (5), 395-415.

(83) Neigh, A. M.; Zwiernik, M. J.; Bradley, P. W.; Kay, D. P.; Park, C. S.; Jones, P. D.; Newsted, J. L.; Blankenship, A. L.; Giesy, J. P. Tree swallow (Tachycineta bicolor) exposure to polychlorinated biphenyls at the Kalamazoo River Superfund Site, Michigan, USA. Environ. Toxicol. Chem. 2006, 25 (2), 428-437.

(84) Neigh, A. M.; Zwiernik, M. J.; Bradley, P. W.; Kay, D. P.; Jones, P. D.; Holem, R. R.; Blankenship, A. L.; Strause, K. D.; Newsted, J. L.; Giesy, J. P. Accumulation of polychlorinated biphenyls from floodplain soils by passerine birds. Environ. Toxicol. Chem. 2006, 25 (6), 15031511.

(85) Neigh, A. M.; Zwiernik, M. J.; Joldersma, C. A.; Blankenship, A. L.; Strause, K. D.; Millsap, S. D.; Newsted, J. L.; Giesy, J. P. Reproductive success of passerines exposed to polychlorinated biphenyls through the terrestrial food web of the Kalamazoo River. Ecotoxicol. Environ. Saf. 2007, 66 (1), 107-118.

(86) Gill, H.; Wilson, L. K.; Cheng, K. M.; Elliott, J. E. An assessment of DDT and other chlorinated compounds and the reproductive success of American robins (Turdus migratorius) breeding in fruit orchards. Ecotoxicology 2003, 12 (1-4), 113-123.

(87) Miljeteig, C.; Gabrielsen, G. W. Contaminants in Brünnich's Guillemots from Kongsfiorden and Bjørnøya in the Period from 1993 to 2007; 2010.

(88) Lucia, M.; Verboven, N.; Strøm, H.; Miljeteig, C.; Gavrilo, M. V.; Braune, B. M.; Boertmann, D.; Gabrielsen, G. W. Circumpolar contamination in eggs of the high-Arctic ivory gull Pagophila eburnea. Environ. Toxicol. Chem. 2015, 34 (7), 1552-1561.

(89) Kristoffersen, S.; Sagerup, K.; Jenssen, B. M.; Warner, N.; Herzke, D.; Gabrielsen, G. W. Miljøgifter $i$ egg fra snøspurv (Plectrophenax nivalis) fra fire bosettinger på Svalbard; Norsk Polarinstitutt: 2012.

(90) Helgason, L. B.; Barrett, R.; Lie, E.; Polder, A.; Skaare, J. U.; Gabrielsen, G. W. Levels and temporal trends (1983-2003) of persistent organic pollutants (POPs) and mercury ( $\mathrm{Hg}$ ) in seabird eggs from Northern Norway. Environ. Pollut. 2008, 155 (1), 190-198.

(91) Herzke, D.; Nygård, T.; Berger, U.; Huber, S.; Røv, N. Perfluorinated and other persistent halogenated organic compounds in European shag (Phalacrocorax aristotelis) and common eider (Somateria mollissima) from Norway: a suburban to remote pollutant gradient. Sci. Total Environ. 2009, 408 (2), 340-348.

(92) Huber, S.; Warner, N. A.; Nygård, T.; Remberger, M.; Harju, M.; Uggerud, H. T.; Kaj, L.; Hanssen, L. A broad cocktail of environmental pollutants found in eggs of three seabird species from remote colonies in Norway. Environ. Toxicol. Chem. 2015, 34 (6), $1296-1308$.

(93) Miljeteig, C.; Strøm, H.; Gavrilo, M. V.; Volkov, A.; Jenssen, B. M.; Gabrielsen, G. W. High levels of contaminants in ivory gull Pagophila eburnea eggs from the Russian and Norwegian Arctic. Environ. Sci. Technol. 2009, 43 (14), 5521-5528.

(94) Braune, B. M.; Mallory, M. L.; Gilchrist, H. G.; Letcher, R. J.; Drouillard, K. G. Levels and trends of organochlorines and brominated flame retardants in ivory gull eggs from the Canadian Arctic, 19762004. Sci. Total Environ. 2007, 378 (3), 403-417.

(95) Braune, B. M. Temporal trends of organochlorines and mercury in seabird eggs from the Canadian Arctic, 1975-2003. Environ. Pollut. 2007, 148 (2), 599-613.

(96) Vander Pol, S. S.; Christopher, S. J.; Roseneau, D. G.; Becker, P. R.; Day, R. D.; Kucklick, J. R.; Pugh, R. S.; Simac, K. S.; York, G. W. In Seabird tissue Archival and Monitoring Proiect: egg collections and analytical results for 1999-2002; Report Number: 7029; NIST: U. F. a. W. S. a. t. U. G. S., Ed.; 2003.

(97) Peck, L. E.; Gilchrist, H. G.; Mallory, C. D.; Braune, B. M.; Mallory, M. L. Persistent organic pollutant and mercury concen- 
trations in eggs of ground-nesting marine birds in the Canadian high Arctic. Sci. Total Environ. 2016, 556, 80-88.

(98) Hoydal, K.; Dam, M. AMAP Faroe Islands heavy metals and POPs core programme 2005-2008; Report no. US 2009:1; 2009; pp 1-55.

(99) Vander Pol, S. S.; Becker, P. R.; Day, R. D.; Ellisor, M. B.; Guichard, A.; Moors, A. J.; Point, D.; Pugh, R. S.; Roseneau, D. G. Seabird Tissue Archival and Monitoring Project: Egg collections and analvtical results for 2002-2005; 2009; DOI: 10.6028/NIST.IR.7562.

(100) Vander Pol, S. S.; Becker, P. R.; Ellisor, M. B.; Moors, A. J.; Pugh, R. S.; Roseneau, D. G. Monitoring organic contaminants in eggs of glaucous and glaucous-winged gulls (Larus hyperboreus and Larus glaucescens) from Alaska. Environ. Pollut. 2009, 157 (3), 755-762.

(101) Vander Pol, S. S.; Becker, P. R.; Berail, S.; Day, R. D.; Donard, O. F. X.; Hobson, K. A.; Moors, A. J.; Pugh, R. S.; Rust, L. B.; Roseneau, D. G. Seabird Tissue Archival and Monitoring Proiect: Egg collections and analutical results for 2006-2009. NISTIR: 2012; Vol. 7562, DOI: 10.6028/NIST.IR.7872.

(102) Heinz, G. H.; Stromborg, K. L. Further declines in organochlorines in eggs of red-breasted mergansers from Lake Michigan, 1977-1978 versus 1990 versus 2002. Environ. Monit. Assess. 2009, 159 (1-4), 163-168.

(103) Custer, C. M.; Custer, T. W.; Dummer, P. M.; Goldberg, D.; Franson, J. C. Concentrations and spatial patterns of organic contaminants in tree swallow (Tachycineta bicolor) eggs at United States and Binational Great Lakes areas of Concern (AOCS), 20102015. Environ. Toxicol. Chem. 2016, 35, 3071.

(104) Custer, T. W.; Dummer, P. M.; Custer, C. M.; Franson, J. C.; Jones, M. Contaminant exposure of birds nesting in Green Bay, Wisconsin, USA. Environ. Toxicol. Chem. 2014, 33 (8), 1832-1839.

(105) Hartig, J. H.; Zarull, M. A.; Ciborowski, J. J.; Gannon, J. E.; Wilke, E.; Norwood, G.; Vincent, A., State of the strait: Status and trends of key indicators; Great Lakes Institute for Environmental Research Occasional Publication: 2007; (5).

(106) Jermyn-Gee, K. An Atlas of Contaminants in Eggs of Fish-eating Colonial Birds of the Great Lakes (1998-2001). Vol. II, Accounts by Chemical; Canadian Wildlife Service: Ontario Region, 2005.

(107) de Solla, S. R.; Weseloh, D. C.; Hughes, K. D.; Moore, D. J. Forty-year decline of organic contaminants in eggs of Herring Gulls (Larus argentatus) from the Great Lakes, 1974 to 2013. Waterbirds 2016, 39 (sp1), 166-179.

(108) Fuentes, L.; Bowerman, W.; Moore, L.; Leith, K.; Drouillard, $\mathrm{K}$. Concentrations of environmental contaminants in herring gull eggs from great lakes colonies in Michigan 2002-2006 and 2008-2012; Report to Michigan Department of Environmental Quality Water Resources Division Lansing, Michigan, USA (MI/DEQ/WRD-14/028.50 pp.); 2014.

(109) Weseloh, D. V.; Hughes, K. D.; Ewins, P. J.; Best, D.; Kubiak, T.; Shieldcastle, M. C. Herring gulls and great black-backed gulls as indicators of contaminants in bald eagles in Lake Ontario, Canada. Environ. Toxicol. Chem. 2002, 21 (5), 1015-1025.

(110) Pekarik, C.; Barker, I. K.; Weseloh, D. C. Organochlorine Contaminants, Immunocompetence and Vitellogenin in Herring Gulls (Larus argentatus) and Great Black-Backed Gulls (Larus marinus) Nesting on Lake Ontario in 2001-2002. Waterbirds 2016, 39 (sp1), 180-201.

(111) Schipper, A. M.; Hendriks, H. W.; Kauffman, M. J.; Hendriks, A. J.; Huijbregts, M. A. Modelling interactions of toxicants and density dependence in wildlife populations. L. Appl. Ecol. 2013, 50 (6), 14691478.

(112) Korsman, J. C.; Schipper, A. M.; Lenders, H. R.; Foppen, R. P.; Hendriks, A. J. Modelling the impact of toxic and disturbance stress on white-tailed eagle (Haliaeetus albicilla) populations. Ecotoxicology 2012, 21 (1), 27-36.

(113) US Army Corps of Engineers, In Environmental Residue Effects Database; AGENCY, U. S. E. P., Ed.; 2002.

(114) Forbes, T.; Forbes, V. A critique of the use of distributionbased extrapolation models in ecotoxicology. Funct. Ecol. 1993, 7 (3), 249-254.
(115) Farmahin, R.; Manning, G. E.; Crump, D.; Wu, D.; Mundy, L. J.; Jones, S. P.; Hahn, M. E.; Karchner, S. I.; Giesy, J. P.; Bursian, S. J. Amino acid sequence of the ligand-binding domain of the aryl hydrocarbon receptor 1 predicts sensitivity of wild birds to effects of dioxin-like compounds. Toxicol. Sci. 2013, 131 (1), 139-152.

(116) Eng, M. L.; Bishop, C. A.; Crump, D.; Jones, S. P.; Williams, T. D.; Drouillard, K. G.; Elliott, J. E. Catbirds are the New Chickens: High Sensitivity to a Dioxin-like Compound in a Wildlife Species. Environ. Sci. Technol. 2017, 51 (9), 5252-5258.

(117) Eng, M. L.; Elliott, J. E.; Jones, S. P.; Williams, T. D.; Drouillard, K. G.; Kennedy, S. W. Amino acid sequence of the AhR1 ligand-binding domain predicts avian sensitivity to dioxin like compounds: In vivo verification in European starlings. Environ. Toxicol. Chem. 2014, 33 (12), 2753-2758.

(118) Gilbertson, M.; Fox, G. A.; Bowerman, W. W. Trends in Levels and Effects of Persistent Toxic Substances in the Great Lakes: Articles from the Workshop on Environmental Results, Hosted in Windsor. Ontario, by the Great Lakes Science Advisory Board of the International loint Commission, September 12 and 13, 1996; Springer Science \& Business Media: 2012; DOI: 10.1007/978-94-011-5290-7.

(119) Forsythe, K. W.; Marvin, C. H. Analyzing the spatial distribution of sediment contamination in the lower Great Lakes. Water Oual. Res. I. Can. 2005, 40 (4), 389-401.

(120) Bakke, T.; Boitsov, S.; Brevik, E.; Gabrielsen, G. W.; Green, N.; Helgason, L. B.; Klungsøyr, J.; Leknes, H.; Miljeteig, C.; Måge, A. Mapping selected organic contaminants in the Barents Sea 2007Kartlegging av utvalgte organiske miljøgifter fra Barentshavet 2007; 8257753246; 2008.

(121) Botts, L.; Krushelnicki, B. The Great Lakes. An Environmental Atlas and Resource Book; ERIC: 1987.

(122) Marvin, C.; Painter, S.; Williams, D.; Richardson, V.; Rossmann, R.; Van Hoof, P. Spatial and temporal trends in surface water and sediment contamination in the Laurentian Great Lakes. Environ. Pollut. 2004, 129 (1), 131-144.

(123) Chang, F.; Pagano, J. J.; Crimmins, B. S.; Milligan, M. S.; Xia, X.; Hopke, P. K.; Holsen, T. M. Temporal trends of polychlorinated biphenyls and organochlorine pesticides in Great Lakes fish, 19992009. Sci. Total Environ. 2012, 439, 284-290.

(124) Custer, T. W.; Custer, C. M.; Hines, R. K.; Gutreuter, S.; Stromborg, K. L.; Allen, P. D.; Melancon, M. J. Organochlorine contaminants and reproductive success of double-crested cormorants from Green Bay, Wisconsin, USA. Environ. Toxicol. Chem. 1999, 18 (6), 1209-1217.

(125) Blus, L. J. Further interpretation of the relation of organochlorine residues in brown pelican eggs to reproductive success. Environ. Pollut. Ser. A 1982, 28 (1), 15-33.

(126) Hendriks, A. J.; Enserink, E. L. Modelling response of singlespecies populations to microcontaminants as a function of species size with examples for waterfleas (Daphnia magna) and cormorants (Phalacrocorax carbo). Ecol. Modell. 1996, 88 (1-3), 247-262.

(127) Cormier, S. M.; Suter, I.; Glenn, W. A method for deriving water-quality benchmarks using field data. Environ. Toxicol. Chem. 2013, 32 (2), 255-262.

(128) Leung, K. M.; Bjørgesæter, A.; Gray, J. S.; Li, W.; Lui, G. C.; Wang, Y.; Lam, P. K. Deriving sediment quality guidelines from fieldbased species sensitivity distributions. Environ. Sci. Technol. 2005, 39 (14), 5148-5156.

(129) Cormier, S.; Suter, G.; Yuan, L.; Zheng, L. A field-based aquatic life benchmark for conductivity in central Appalachian streams; EPA/600/ R-10; 2011. 